\title{
Students' Perceptions on Using Zoom Application in Debate Course during Crisis Remote Teaching
}

\author{
Mohammad Fatoni ${ }^{1}$, Rafif Ariq Lukman ${ }^{2}$, Khoirul Wafa ${ }^{3}$
}

\author{
1,2,3 Universitas Nahdlatul Ulama Sunan Giri, Bojonegoro, Indonesia \\ *Corresponding author. E-mail address: mohammadfatoni@unugiri.ac.id
}

\begin{abstract}
This research aims to know the students' perception of using zoom application in a debate course during crisis remote teaching. The government of Indonesia gave an order to the Higher Education Commission, asked them to start preparing for crisis remote teaching via online learning modes, rescheduled all of the exams given, and helped the students online learning until the COVID-19 crisis remained unchanged. Online learning is the leading choice for instruction within the middle of the Covid-19 flare-up. In Indonesia, not all students are commonplace with the online learning framework, so this has become a new thing that requires adjustment. The research design used is mix method in this research. There are 26 university students who participate in this research. This research was presented quantitatively and descriptively to reveal the students' perceptions and difficulties comprehensively. The research finds ZOOM Application gets a positive perception because it is effective and comfortable. However, the problems that the students face are the device to do online learning and internet connection. It is suggested that zoom app is still appropriate to be used in debate course class due to many advantages than the problems that emerge during crisis remote teaching.
\end{abstract}

Keywords: Students' Perceptions, ZOOM Meeting Application, Debate Course, Crisis Remote Teaching.

\section{INTRODUCTION}

As of 14th March 2020, cases of COVID-19 in the country were 165,062, with 3,229 deaths. In that situation, as the enormous reaction to the COVID-19, all of the country's educational institutions were closed by the Indonesian government on 16th June 2020. The government of Indonesia gave an order to the Higher Education Commission asked to start preparing for crisis remote teaching via online learning modes, reschedule all of the exams given, and help the students online learning until the COVID-19 crisis remains unchanged. We had to face this situation and also started every learning via online in Indonesia, there are still activities of education that impose the students make face-to-face meetings in class. However, with the Covid-19 pandemic struck in Indonesia, all activities must be done at home to prevent it from spreading. 
Journal of Literature, Linguistics, and Language Teaching

Volume 2 (2) 2021

ISSN: 2746-8968 (online)

https://journal.unesa.ac.id/index.php/nld/index

Online learning is the leading choice for instruction within the middle of the Covid-19 flare-up. In Indonesia, not all students are commonplace with the online learning framework, so this has become a modern thing that requires adjustment. Students' sees of this learning framework will moreover shift. Subsequently, this study examines how students' views on online learning are connected in their teaching. In other words, research is needed to know that within the middle of the Covid-19 widespread understudies were still learning well or not through the online learning framework. The investigation understudy discernments almost application that more justifiable on talking lesson after encountering the learning preparation through online learning should be done.

There are some researches about online learning that use ZOOM Meeting. Mihhailova (2006) claims online learning is not acceptable for the students because the students do not have any knowledge of the software that they used, and another study from El-Seoud et al. (2014) using online learning totally give so much motivation and involvement for students even though some of the students must own the unique ability and tools for making it without any trouble.ZOOM Meeting is a better applicationbecause the application can make the students' communication orally than other application that conducts written communication activities (Haqien \& Rahman, 2020). Learning English through online learning has many advantages, such as students can be more independent to learn so that they do not depend on the teacher, time and place to learn can also be flexible anytime and anywhere (Anggraini et al., 2021). There is a conflicting argument between what Mihhailova and El-Seoud et al about the use of online applications. Therefore, it was needed to investigate the students' perception on using zoom application in debate course during crisis remote teaching in Indonesian context to know the students' perception, benefit and challenges as Indonesian government suggestion to do reflection in our teaching learning process during crisis remote teaching.

There are two research problems proposed in this research. They are the Students' perception of using ZOOM in debating course during the Covid-19 Pandemic and the students' difficulties found in using ZOOM in debating course during the Covid-19 Pandemic are. Therefore, it is necessary to investigate students' perception of using zoom application in debate course during crisis remote teaching that the understudy has utilized in debate.

\section{METHOD}

The method used in the research was mix method. This method combined between quantitative and qualitative research data. This research took place in one of the private universities in East Java. And the participant of this study was 26 students, with 22 female students and 4 male who are involved. The researchers used three instruments in this study, namely observation, questionnaires, and interviews. First, the researcher did the observation in 4 times meetings. The observation were done by the researcher using field note to observe the situation of the class. Secondly, the researcher shared the questionnaire in the google form. In conducting this study, the researcher conducted close-ended responses to questions in a web questionnaire using Google Form. Then, they are distributed to a WhatsApp group of sixth-semester students of university. Closed questions were structured because they can frequently produce responses received by statistical analysis. Furthermore, after being validated, the next step was to 
New Language Dimensions

Journal of Literature, Linguistics, and Language Teaching

Volume 2 (2) 2021

ISSN: 2746-8968 (online)

https://journal.unesa.ac.id/index.php/nld/index

distribute questionnaires and conduct interviews with English language education students to collect valid data.

\section{FINDINGS AND DISCUSSION}

Based on the observation done by the researcher using field notes, the lecturer started the class on time as always but needed a little bit prepared for the class, and needed more time to gather all of the students to join in ZOOM until 30 minutes the lecturer asked to some of the students to give an announcement to other students that class has begun, finally, there were some students not able to join the class because of some reasons. Some of them also absent without any reasons.

The second observation was started by the same condition just like on the first observation, but while the class was going, several things happened there were some of the students got difficulty entering the class because the signal was terrible, this information was shared by other students that got information from WhatsApp group.

Several times later, there were some of the participants who did not respond to the lecturer even though the participants were still online and on a good connection. On the other side, there were students that reconnect because the weather impacted the signal. Furthermore, for information, the students only turn on the video when they turn to speak up or want to ask.

A few students got trouble entering the lesson since the signal was terrible. This information was shared by other students that got information from the WhatsApp group. The last observation, the observation was begun by the same condition instead like on the previous observation, but while the lesson was going, there were a few things that happened, there were a few of the students got trouble entering the course since the signal was awful, this information was shared by other students that got information from WhatsApp group.

In this questionnaire, there were fifteen questions about students' perceptions on using zoom using zoom application in debate course online. The questions used within the survey to investigate two research issues around students' perceptions. It is suggested to utilize an adjusted Likert scale for cases with five levels, SA (Strongly Agree), A (Agree), N (neutral), DA (Disagree), SDA (Strongly Disagree).

The primary research issue is investigating students' perceptions on utilizing the zoom application in debate courses online. To reply to the primary research question, the researcher distributed questionnaires, and there were 26 students voluntarily participating in filling out the questionnaire. In addition, the researcher moreover conducted interviews with five students to strengthen and get extra data

Table 1. Questionnaire data about students' perceptions

\begin{tabular}{l|l|c|c|c}
\multirow{2}{*}{$\begin{array}{l}\text { No. } \\
\text { Statements }\end{array}$} & \multicolumn{1}{|c|}{ Questionnaire statements } & Scale & Frequency & Percentage \\
\hline \multirow{3}{*}{1.} & The lecturer explains the use of & & & \\
\cline { 3 - 5 } & ZOOMApps and debate material & $\mathrm{SA}$ & 4 & $15.4 \%$ \\
\cline { 3 - 5 } & well & $\mathrm{N}$ & 0 & $65.4 \%$ \\
\cline { 3 - 5 } & & $\mathrm{DA}$ & 4 & $0 \%$ \\
\cline { 3 - 5 } & & $\mathrm{SDA}$ & 1 & $3.8 \%$ \\
\hline \multirow{3}{*}{} & & $\mathrm{SA}$ & 11 & $42.3 \%$ \\
\cline { 3 - 5 } & & $\mathrm{A}$ & 10 & $38.5 \%$
\end{tabular}


New Language Dimensions

Journal of Literature, Linguistics, and Language Teaching

Volume 2 (2) 2021

ISSN: 2746-8968 (online)

https://journal.unesa.ac.id/index.php/nld/index

\begin{tabular}{|c|c|c|c|c|}
\hline \multirow[t]{3}{*}{2.} & \multirow{3}{*}{$\begin{array}{l}\text { Debate learning through ZOOM } \\
\text { is effective during the Covid-19 } \\
\text { pandemic }\end{array}$} & $\mathrm{N}$ & 0 & $0 \%$ \\
\hline & & DA & 2 & $7.7 \%$ \\
\hline & & SDA & 3 & $11.5 \%$ \\
\hline \multirow{5}{*}{3.} & \multirow{5}{*}{$\begin{array}{l}\text { Your Debate skills improve } \\
\text { during learning through ZOOM }\end{array}$} & SA & 3 & $11.5 \%$ \\
\hline & & A & 12 & $46.1 \%$ \\
\hline & & $\mathrm{N}$ & 2 & $7.69 \%$ \\
\hline & & DA & 8 & $30.8 \%$ \\
\hline & & SDA & 1 & $3.8 \%$ \\
\hline \multirow{5}{*}{4.} & \multirow{5}{*}{$\begin{array}{l}\text { You are motivated and } \\
\text { enthusiastic to learn Debate } \\
\text { through ZOOM during the } \\
\text { Covid-19 pandemic }\end{array}$} & SA & 2 & $7.7 \%$ \\
\hline & & $\mathrm{A}$ & 12 & $46.2 \%$ \\
\hline & & $\mathrm{N}$ & 0 & $0 \%$ \\
\hline & & DA & 11 & $42.3 \%$ \\
\hline & & SDA & 1 & $3.8 \%$ \\
\hline \multirow{5}{*}{5.} & \multirow{5}{*}{$\begin{array}{l}\text { You are comfortable with } \\
\text { distance learning through the } \\
\text { ZOOM app }\end{array}$} & SA & 3 & $11.5 \%$ \\
\hline & & A & 6 & $23.1 \%$ \\
\hline & & $\mathrm{N}$ & 2 & $7.6 \%$ \\
\hline & & DA & 10 & $38.5 \%$ \\
\hline & & SDA & 5 & $19.2 \%$ \\
\hline \multirow{5}{*}{6.} & \multirow{5}{*}{$\begin{array}{l}\text { You feel your Debate skills have } \\
\text { improved by learning speaking } \\
\text { through ZOOM during the } \\
\text { COVID-19 pandemic }\end{array}$} & SA & 3 & $11.5 \%$ \\
\hline & & $\mathrm{A}$ & 13 & $50 \%$ \\
\hline & & $\mathrm{N}$ & 0 & $0 \%$ \\
\hline & & $\mathrm{DA}$ & 6 & $23.1 \%$ \\
\hline & & SDA & 4 & $15.4 \%$ \\
\hline
\end{tabular}

According to the data obtained from the questionnaire showed the highest frequency with a percentage of strongly agree 4 students (15.4\%) and agree 17 students (65.4\%) agree with the question. Based on the data above, it is known that the lecturer does her job well to explain the ZOOMApps and the debate material. This is also supported by the interview. The finding shows that the teacher is good in teaching the material about debate.

(I.1) Do the lecturer explains the use of ZOOMApps and debate material well?

S1 : In my opinion, the use of ZOOMApps and debate material were explained well and easy to understand via zoom."

S2 : So do I. I think it's very good. She explained the material well, even giving examples of the material."

This finding is different from the previous study from Mihhailova (2006), which conducted a study to investigate how the use of online learning is not acceptable for the students because the students do not have any knowledge of the software they used. In Mihhaillova's study, the participants were students from an open university with a wide range of socioeconomic, cultural, educational backgrounds and low student information about this application, which at least to some degree represents the primary issues faced by all Estonian institutions that use online learning. Therefore, the finding was not in line.

In term of motivation, a percentage of strongly agree 2 students (7.7\%) and agree 12 students (46.2\%) agree with the questions. This is in line with the previous study from (2014) claiming that online learning will increase student motivation and involvement to memorize and offer assistance to become independent learners. Furthermore, the result of this research is in line with this previous study from Abou El-Seoud et al. (2014), but the difference is only the 


\section{New Language Dimensions}

Journal of Literature, Linguistics, and Language Teaching

Volume 2 (2) 2021

ISSN: 2746-8968 (online)

https://journal.unesa.ac.id/index.php/nld/index

application that is used for class. Then the students feel the same time with their ability that grew up because of debate class in ZOOM. Students spirit, while they are in class, in this section, the data obtained from the questionnaire, showed that the highest frequency with a percentage of $46,2 \%$, agrees with the question. However, there are high responses in percentage $42,3 \%$ in disagreeing with the question, and the similar result also from the interview showed a similar result, there are students that agree with this case. On another side also there is a student that disagrees about the statement, of course, they have the reason for their response to the statement from the observation also the researcher can see there is some preparation from the lecturer and some of the exciting presentations from her that make the students feel they enjoy the class but in another side, there is some of the trouble that they have to face in meeting that makes them feel annoyed with it and downgrade their spirit. Teaching English by using zoom also affected the students independent learning and managing time (Bawanti \& Arifani, 2021; Kustiyani, 2021; Suardi, 2020)

Table 2. Questionnaire data about students' Difficulties

\begin{tabular}{|c|c|c|c|c|}
\hline $\begin{array}{l}\text { No. } \\
\text { Statements }\end{array}$ & Questionnaire statements & Scale & Frequency & Percentage \\
\hline \multirow{5}{*}{1.} & \multirow{5}{*}{$\begin{array}{l}\text { You want to learn the learning } \\
\text { media used by teachers during } \\
\text { the Covid-19 pandemic }\end{array}$} & SA & 5 & $19.2 \%$ \\
\hline & & $\mathrm{A}$ & 19 & $73.1 \%$ \\
\hline & & $\mathrm{N}$ & 0 & $0 \%$ \\
\hline & & $\mathrm{DA}$ & 2 & $7.7 \%$ \\
\hline & & SDA & 0 & $0 \%$ \\
\hline \multirow{5}{*}{2.} & \multirow{5}{*}{$\begin{array}{l}\text { You ask the lecturer when you } \\
\text { have difficulty learning Debate } \\
\text { through ZOOM }\end{array}$} & SA & 1 & $3.8 \%$ \\
\hline & & $\mathrm{A}$ & 21 & $80.8 \%$ \\
\hline & & $\mathrm{N}$ & 0 & $0 \%$ \\
\hline & & DA & 3 & $11.5 \%$ \\
\hline & & SDA & 1 & $3.8 \%$ \\
\hline \multirow{5}{*}{3.} & \multirow{5}{*}{$\begin{array}{l}\text { You are diligent in doing the } \\
\text { Debate assignments given by the } \\
\text { teacher through ZOOM during } \\
\text { the Covid-19 pandemic }\end{array}$} & SA & 4 & $15.4 \%$ \\
\hline & & A & 13 & $50 \%$ \\
\hline & & $\mathrm{N}$ & 2 & $7.69 \%$ \\
\hline & & DA & 3 & $11.5 \%$ \\
\hline & & SDA & 4 & $15.4 \%$ \\
\hline \multirow{5}{*}{4.} & \multirow{5}{*}{$\begin{array}{l}\text { You are still learning Debate } \\
\text { even though there are no } \\
\text { assignments during the Covid-19 } \\
\text { pandemic }\end{array}$} & SA & 2 & $7.7 \%$ \\
\hline & & $\mathrm{A}$ & 18 & $69.2 \%$ \\
\hline & & $\mathrm{N}$ & 0 & $0 \%$ \\
\hline & & $\mathrm{DA}$ & 6 & $23.1 \%$ \\
\hline & & SDA & 0 & $0 \%$ \\
\hline \multirow{5}{*}{5 . } & \multirow{5}{*}{$\begin{array}{l}\text { You have problems with the } \\
\text { device you are using in } \\
\text { participating in Debate learning } \\
\text { through ZOOM during the } \\
\text { COVID-19 pandemic }\end{array}$} & SA & 9 & $34.6 \%$ \\
\hline & & $\mathrm{A}$ & 13 & $50 \%$ \\
\hline & & $\mathrm{N}$ & 0 & $0 \%$ \\
\hline & & DA & 4 & $15.4 \%$ \\
\hline & & SDA & 0 & $0 \%$ \\
\hline \multirow{5}{*}{6.} & \multirow{5}{*}{$\begin{array}{l}\text { You are having problems with the } \\
\text { operator signal you are using } \\
\text { when taking a Debate class via } \\
\text { ZOOM during the COVID-19 } \\
\text { pandemic }\end{array}$} & SA & 10 & $38.5 \%$ \\
\hline & & A & 14 & $53.8 \%$ \\
\hline & & $\mathrm{N}$ & 0 & $0 \%$ \\
\hline & & $\mathrm{DA}$ & 2 & $7.7 \%$ \\
\hline & & SDA & 0 & $0 \%$ \\
\hline \multirow[b]{3}{*}{7.} & \multirow{3}{*}{$\begin{array}{l}\text { You face limited internet quota in } \\
\text { participating in debate lessons }\end{array}$} & SA & 10 & $38.5 \%$ \\
\hline & & A & 11 & $42.3 \%$ \\
\hline & & $\mathrm{N}$ & 0 & $0 \%$ \\
\hline
\end{tabular}


Journal of Literature, Linguistics, and Language Teaching

Volume 2 (2) 2021

ISSN: 2746-8968 (online)

https://journal.unesa.ac.id/index.php/nld/index

\begin{tabular}{|c|c|c|c|c|}
\hline & through ZOOM during the & DA & 5 & $19.2 \%$ \\
\hline & COVID-19 pandemic & SDA & 0 & $0 \%$ \\
\hline \multirow{5}{*}{8.} & \multirow{5}{*}{$\begin{array}{l}\text { You get assistance in the form of } \\
\text { internet quota subsidies in } \\
\text { participating in Debate learning } \\
\text { through ZOOM during the } \\
\text { COVID-19 pandemic }\end{array}$} & SA & 4 & $15.4 \%$ \\
\hline & & $\mathrm{A}$ & 15 & $57.7 \%$ \\
\hline & & $\mathrm{N}$ & 0 & $0 \%$ \\
\hline & & DA & 6 & $23.1 \%$ \\
\hline & & SDA & 1 & $3.8 \%$ \\
\hline \multirow{5}{*}{9.} & \multirow{5}{*}{$\begin{array}{l}\text { You often miss class in Debate } \\
\text { learning via ZOOM during the } \\
\text { COVID-19 pandemic }\end{array}$} & SA & 3 & $11.5 \%$ \\
\hline & & A & 7 & $26.9 \%$ \\
\hline & & $\mathrm{N}$ & 0 & $0 \%$ \\
\hline & & DA & 12 & $46.2 \%$ \\
\hline & & SDA & 4 & $15.4 \%$ \\
\hline
\end{tabular}

The second research problem is investigating students' difficulties using ZOOM in debating courses during the Covid-19 Pandemic. Students show up to be interested in ecourses, but the level of knowledge regarding specifics of web-based learning and approximately e-courses offered was unexpectedly low. The first is about the students want to learn about the application or not in this point the data obtained from the questionnaire showed that the highest frequency, a percentage of $73.1 \%$, agrees with the questions presented. Then deepened with interviews, the results obtained that the answers of dominant students want to learn the learning media used by the lecturer.

(I.7) Do you want to learn about the learning media used by teachers during the Covid19 pandemic?

S1: Yes, I do as long as the amount is within 2-3 learning applications in one semester

S2: Yes, I do because it is interesting to explore the learning media.

This finding is in line with the previous study that many students enjoy learning about the ZOOM Meeting application (Sandu et al., 2021).

Then, it is about problems with the devices which are used in Debate learning through ZOOM during crisis remote teaching. The data obtained from the questionnaire showed that the highest frequency with a percentage of $50 \%$ agree with the questions presented and 34,6\% strongly agree with the questions. It means many of them get into trouble with their device for some reason, but the data collected from the interview shows some are fine. Their device can handle it.

(I.11) Do you have problems with the device you use in participating in Debate learning through ZOOM during the COVID-19 pandemic?

$\mathrm{S} 1$ : The device I'm using is experiencing overheating every time debating is done with zoom.

S2 : No, I do not

S3 : No, my device works well. 
Journal of Literature, Linguistics, and Language Teaching

Volume 2 (2) 2021

ISSN: 2746-8968 (online)

https://journal.unesa.ac.id/index.php/nld/index

However, based on the observation in the online class, one or several students get into trouble with their device to conduct online learning and also an internet connection. This is also proved with the interview with the students

(I.12) Are you having problems with the signal of the mobile network operator you are using when taking a Debate class via ZOOM during the COVID-19 pandemic?

S1 : Yes, when I used X mobile network operator, but it worked well when I used my neighbors' the hotspot that use other mobile network operators

S2 : I usually get trouble with internet connection

S3 : Yes, I had an obstacle like an internet connection, but not often.

This is in line with the previous study that claims that almost every minutes there is one or several students are detected get any problems, overheating, or other problems during online learning because they have low capacity of memory in their device and low internet connection in a certain area (Aurelliani, 2021; Mundiri et al., 2021; Saha et al., 2021).

From the data analysis above, the researcher found that students' perceptions of opportunities and challenges in using ZOOM in debating courses during crisis remote teaching. Pandemics differed from one another. Using ZOOM in debating during this pandemic has advantages and disadvantages, where the effects felt by students are also different. Students have difficulty in learning because the learning systems used during the pandemic have never been used previously (Pengnate \& Rattanapong, 2021). Based on students' responses to fill questionnaires and interviews, students' perceptions of using zoom while studying at home is positive, and the ZOOM Meeting is quite helpful in learning debate during crisis remote teaching.

\section{CONCLUSION}

The students have positive perception on learning English debate using ZOOM Meeting during crisis remote teaching. Some of them claim that learning English while at home is quite good. They argue that it is the only way to keep learning in online mode as long as crisis remote teaching is still taking place. So, they can still learn even if not directly face to face. Then, learning English debate using ZOOM Meeting during crisis remote teaching was fine, and the material delivered by the teacher was well received. The researcher found some difficulties that students face in virtual meetings using ZOOM Meeting in debate class. The difficulties are about their device to do online learning, but not all of them, and low internet connection in certain areas.

\section{REFERENCES}

Abou El-Seoud, M. S., Taj-Eddin, I. A. T. F., Seddiek, N., El-Khouly, M. M., \& Nosseir, A. (2014). E-learning and students' motivation: A research study on the effect of e-learning on higher education. International Journal of Emerging Technologies in Learning (IJET), 9(4), 20-26. 
Journal of Literature, Linguistics, and Language Teaching

Volume 2 (2) 2021

ISSN: 2746-8968 (online)

https://journal.unesa.ac.id/index.php/nld/index

Anggraini, I., Jamaluddin, J., \& Amalia, S. (2021). Students'perceptions Of Online Learning English During The Covid-19 Pandemic. UIN Sulthan Thaha Saifuddin Jambi.

Aurelliani, D. (2021). Using Sparkol Video Scribe With Zoom Application To Imrpove

Students'speaking Skill Of The Tenth Grade Os Sma Lifekill Teknologi ....

repository.univ-tridinanti.ac.id. http://repository.univ-tridinanti.ac.id/id/eprint/3647

Bawanti, P. K. D., \& Arifani, Y. (2021). The Students' Perceptions of Using Zoom

Application on Mobile Phone in Improving Speaking Skills During Online Learning at

Ban Loeiwangsai School, Loei .... Journal of English Teaching, Literature ....

http://journal.umg.ac.id/index.php/jetlal/article/view/2212

Haqien, D., \& Rahman, A. A. (2020). Pemanfaatan zoom meeting untuk proses pembelajaran pada masa pandemi covid-19. SAP (Susunan Artikel Pendidikan), 5(1).

Kustiyani, A. (2021). Implementation problem based learning model using zoom meeting application. Journal of Physics: Conference Series. https://iopscience.iop.org/article/10.1088/1742-6596/1823/1/012077/meta

Mihhailova, G. (2006). E-learning as internationalization strategy in higher education: Lecturer's and student's perspective. Baltic Journal of Management.

Mundiri, A., Mahmud, M. E., Ubaidillah, M., \& ... (2021). Learning Agility During Pandemic; Outstanding Strategy in Language Learning by Using Zoom Application. Journal of Physics .... https://iopscience.iop.org/article/10.1088/17426596/1779/1/012066/meta

Pengnate, W., \& Rattanapong, C. (2021). A Study of Students' Satisfaction on English Instruction Using Zoom Application. 2021 6th International .... https://ieeexplore.ieee.org/abstract/document/9465873/

Saha, S., Roy, H., \& Ray, K. (2021). Online anatomy lecture using zoom application and its learning experience of undergraduate medical students. researchgate.net. https://www.researchgate.net/profile/Satyajit-Saha4/publication/353599796_o_r_i_g_i_n_a_1_a_r_t_i_c_1_e_Online_anatomy_lecture_usi ng_zoom_application_and_its_learning_experience_of_undergraduate_medical_student s/links/6104f7351ca20f6f86ed91eb/O-R-I-G-I-N

Sandu, R., Karim, S., \& Kayastha, M. (2021). E-Learning Challenges Using Zoom and Application of Artificial Intelligence To Improve Learning in Australia Higher Education Institutes. Part of the Multi Conference On ..., Nadezhda 2020, 109-114. https://biblio.ugent.be/publication/8717390/file/8717395\#page $=124$

Suardi, M. (2020). The Effectiveness of Using the Zoom Cloud Meetings Application in the Learning Process. International Conference on Science and Advanced .... https://ojs.unm.ac.id/icsat/article/view/17730 